\title{
21. CLAY MINERAL STRATIGRAPHY AND RELATED DIAGENESIS IN THE DEEP SEA DRILLING PROJECT LEG 60 SEDIMENTS ${ }^{1}$
}

\author{
Katherine M. Balshaw, Geology Department, Rice University, Houston, Texas
}

\begin{abstract}
X-ray diffraction studies on the $<2-\mu \mathrm{m}$ fraction of clay samples from cores collected on DSDP Leg 60 in the Mariana Trough and western Pacific plate (Sites 453, 454, and 452) were analyzed to explore the clay mineral stratigraphy of the region. Certain sites (Sites 453,456 , and 458) were used to examine the relationship between authigenic clay mineral development and variations in the calcium and magnesium concentrations in the pore water.

This study is a continuation of a similar investigation on DSDP Leg 59 pelagic clays in the South Philippine Sea. These combined analyses indicate that the detrital clay components in the South Philippine Sea sediments have not changed markedly since the Neogene. Clay minerals in the $<2-\mu \mathrm{m}$ separates consist of $>80$ percent smectite with minor amounts of chlorite, illite, kaolinite, and possibly vermiculite. However, the smectite percentage is enhanced by the formation of authigenic smectite presumably derived from the alteration of volcanic glass in the sediments.

Study of the authigenic clay components shows a general increase in smectite downhole associated with increasing calcium and decreasing magnesium in the sediment pore waters. In addition to dioctahedral smectite (montmorillonite), the authigenic study reveals traces of trioctahedral smectite (saponite), celadonite, possibly "proto-celadonite," and wairakite in various samples.
\end{abstract}

\section{INTRODUCTION}

This research has two objectives. The first involves expanding the clay-mineral stratigraphy of the South Philippine Sea which was initially developed from Leg 59 sites in the region (Balshaw, in press). The second objective is exploration of the relationship between authigenic clay formation and the changes observed downhole in the calcium and magnesium concentrations in the pore water.

The clay stratigraphy study in the central South Philippine Sea (DSDP Holes 447A, 449, and 450) is described by Balshaw (in press). The same analytical techniques are applied to clay separates from Leg 60 (Sites 453, 454, and 452) in the Mariana Trough, and western Pacific plate. A Cenozoic stratigraphic history is developed from these analyses. Sediment sources are also discussed.

The authigenic clay study involves XRD (X-ray diffraction) analyses of clay separates from samples of Leg 60 Sites 453,456 , and 458 . The sample preparation is essentially identical to that employed for the stratigraphic study, except in the initial disaggregation of the samples where the sediments are crushed to dislodge authigenic growths adhering to grain surfaces. Changes in the mineralogy and abundance of authigenic components are discussed in conjunction with shipboard analyses describing the variations in calcium and magnesium concentrations in the pore water with depth.

\section{STRATIGRAPHIC STUDY}

\section{ANALYTICAL METHODS}

Twenty samples, averaging $5 \mathrm{~cm}^{3}$ each, were dispersed in deionized water by the ultrasonic probe. The samples were then chemically

\footnotetext{
${ }^{1}$ Initial Reports of the Deep Sea Drilling Project, Volume 60.
}

treated through a series of steps to remove carbonates, soluble salts, and amorphous material. The entire procedure is discussed in greater detail by Balshaw (in press); it includes use of $0.1 \mathrm{~N}$ sodium acetate/ acetic acid solution ( $p \mathrm{H} \mathrm{5})$ to dissolve carbonates and soluble salts and $0.2 \mathrm{M}$ ammonium oxalate/oxalic acid solution to dissolve amorphous Fe hydroxides and oxyhydroxides. A hydrogen peroxide treatment to eliminate organic materials was not used because it alters less crystalline smectites. The $<2-\mu \mathrm{m}$ separates are obtained by settling of the treated sample through a deionized water column. The resulting clay slurries are then treated with $1.0 \mathrm{M} \mathrm{MgCl}$ solution to saturate the clay exchange sites with $\mathrm{Mg}$ ions. The slurries are applied to glass slides, dried at room temperature, and X-rayed before and after glycolation and possible heating.

\section{Results}

\section{Site $\mathbf{4 5 2}$}

This site is located east of the Mariana Trench on the western margin of the Pacific plate (latitude $17^{\circ}$ $40.19^{\prime} \mathrm{N}$; longitude $148^{\circ} 37.73^{\prime} \mathrm{E}$ ) in 5858 meters of water. Hole 452 penetrates 28 meters into the Quaternary pelagic clay cover. Hole $452 \mathrm{~A}$, located adjacent to Hole 452 , penetrates 46.5 meters through the pelagic clay and reaches Upper Cretaceous radiolarian mudstone in the lower 0.2 meters of the hole. Samples for clay analyses are taken from near the surface down to a depth of 28 meters at both holes. Sample coverage was best in Hole 452; therefore, its samples were selected for the clay determinations.

The clay separates $(<2-\mu \mathrm{m})$ are dominated by smectite (see Fig. 1), which increases steadily down the section from 83 percent near the surface to 92 percent at 22.7 meters. The major glycolated smectite peaks are broad, indicating poor crystallinity; they extend from 16 to $20 \AA$ with little change down the core. The center of these peaks occurs at $17.7 \AA$ near the surface and decreases down the core to a value of $17 \AA$ at a depth of 17.7 meters. Chlorite decreases from 10 percent near the surface to 5 percent at a depth of 5 meters and maintains 


\begin{tabular}{|lc|c|}
\hline $\begin{array}{l}\text { Core- } \\
\text { Section }\end{array}$ & $\begin{array}{c}\text { Interval } \\
(\mathrm{cm})\end{array}$ & $\begin{array}{c}\text { Depth below } \\
\text { Sea Floor }(\mathrm{m})\end{array}$ \\
\hline $1 \cdot 1$ & $140-142$ & $1.40-1.42$ \\
1.4 & $80-82$ & $5.30-5.32$ \\
$2 \cdot 4$ & $120-122$ & $14.70-14.72$ \\
$2 \cdot 6$ & $120-122$ & $17.70-17.72$ \\
$3-3$ & $120-122$ & $22.70-22.72$ \\
\hline
\end{tabular}

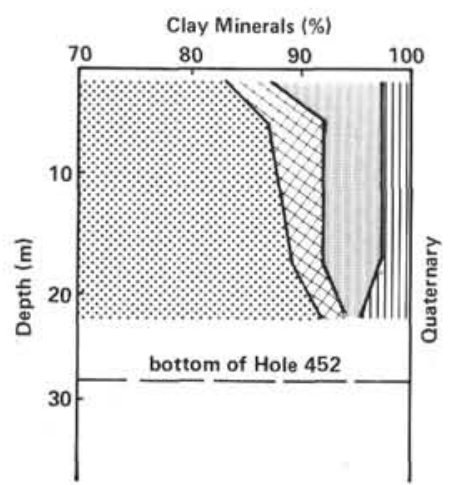

Figure 1. Site 452 , percentages of clay minerals in the $<2-\mu \mathrm{m}$ separates.

this level down the section. Illite averages over 4 percent and kaolinite slightly less than 4 percent down the section. There may be minor amounts of vermiculite in these samples, but this cannot be confirmed by K saturation and heating because of low peak amplitudes and masking by chlorite and illite peaks.

None of the sites drilled on Leg 60 in the Mariana Trough or fore-arc contains pelagic clay units. Clay sedimentation was masked by volcanic and biogenic sediments. However, samples were analyzed from two sites, Sites 453 and 454 (Hole 454A and piston core SP4E), to determine if any detectable changes occur in the detrital clay constituents.

\section{Site $\mathbf{4 5 3}$}

This site is located at the western Mariana Trough off the eastern flank of the Mariana Ridge (latitude $17^{\circ}$ $54.42^{\prime} \mathrm{N}$; longitude $143^{\circ} 40.95^{\prime} \mathrm{E}$ ) in 4693 meters of water. It penetrates 446 meters of dominantly volcaniclastic sediments. Samples were selected from Pleistocene through lower Pliocene clay, mud, and claystone units ranging in depth from near the surface to a depth of 276.7 meters.

The clay components of the lower Pliocene to upper Pleistocene sediments show a general but slight decrease in smectite from approximately 98 to 70 percent in the clay separates of the younger sediments, whereas upper Pleistocene sediments contain up to 98 percent smectite (Fig. 2). This smectite variation is most likely a function of summing the clay mineral species to equal 100 percent. The increase in chlorite in the lower Pliocene to upper Pleistocene sediments would cause an associated reduction in the calculated percentage of smectite in these sediments relative to the upper Pleistocene sediments. The major glycolated smectite peaks in these sediments are broad and extend from 16 to $19 \AA$. The peaks center at $16.99 \AA$ near the surface and shift down the section to a maximum of $19.2 \AA$ at a depth of 125.7 meters. Below this, to a depth of 276.6 meters, the central peak remains at $17.7 \AA$.

Of the three definitely detrital components, illite shows a slight decrease down the section, and chlorite and kaolinite maintain fairly equal proportions except in the upper Pleistocene section, where chlorite is more abundant than the combined illite and kaolinite percent-

\begin{tabular}{|r|c|c|}
\hline $\begin{array}{c}\text { Core- } \\
\text { Section }\end{array}$ & $\begin{array}{c}\text { Interval } \\
(\mathrm{cm})\end{array}$ & $\begin{array}{c}\text { Depth below } \\
\text { Sea Floor }(\mathrm{m})\end{array}$ \\
\hline $1-3$ & $120-122$ & $4.20-4.22$ \\
$2 \cdot 4$ & $120-122$ & $14.70-14.72$ \\
$4-2$ & $120-122$ & $30.70-30.72$ \\
45 & $120-122$ & $35.20-35.22$ \\
$8-2$ & $120-122$ & $68.70-68.72$ \\
$10-2$ & $120-122$ & $87.70-87.72$ \\
142 & $119-121$ & $125.69-125.71$ \\
$15-1$ & $119-121$ & $133.69-133.71$ \\
$22-2$ & $120-122$ & $201.70-201.72$ \\
$30-1$ & $113-115$ & $276.63-276.66$ \\
& & \\
\end{tabular}

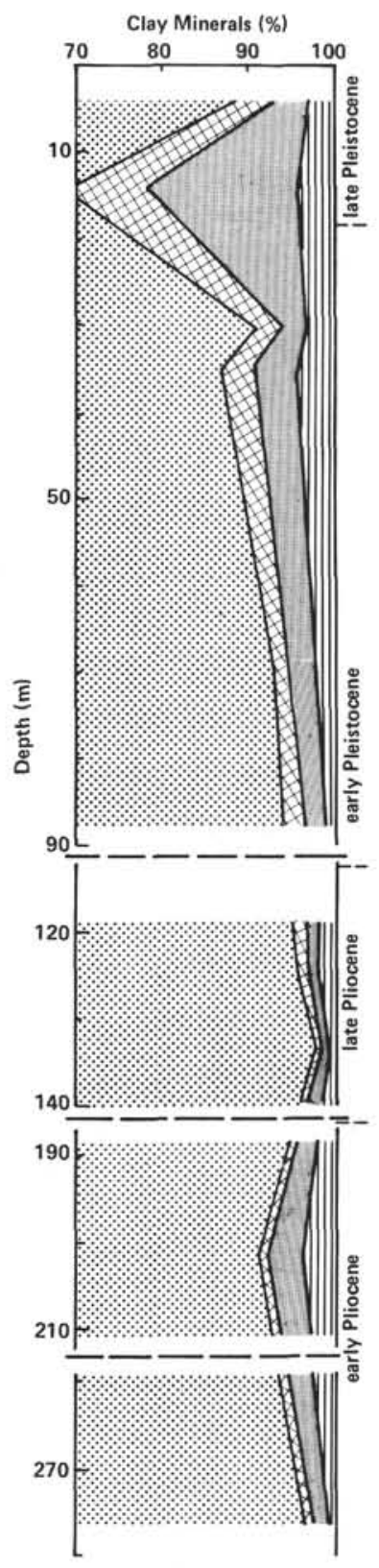

Figure 2. Site 453 , percentages of clay minerals in the $<2-\mu \mathrm{m}$ separates.

ages. As at the previous site, vermiculite may be present, but this cannot be confirmed.

The combined Holes 454, 454A, and piston core SP4E at Site 454 are located near the center of the Mariana Trough (latitude $18^{\circ} 00.78^{\prime} \mathrm{N}$; longitude $144^{\circ}$ $\left.31.92^{\prime} \mathrm{E}\right)$ in 3816 meters of water. Together they penetrated to a depth of 171.5 meters in dominantly radiolarian and nannofossil-rich volcaniclastic sediments. It was necessary to select samples from all three holes to provide adequate depth coverage.

SP4E is a piston core used for the site survey. It penetrated to a depth of 7.5 meters. The first core at Site 454 was recovered from a depth of 10.0 meters and the hole was terminated at a depth of 38.5 meters. At Hole $454 \mathrm{~A}$, cores were recovered at depths from 0.5 to 10.0 
meters and from 38.5 to 67.0 meters. Samples used in this study cover the time interval from early to late Pleistocene.

Smectite shows a general decrease in abundance down the section, from 96 to 85 percent within the upper through lower Pleistocene section (Fig. 3). The major glycolated smectite peaks are broad and extend from 16.7 to $22.0 \AA$. The major peak appears at $18 \AA$ near the surface and decreases down the section to $16.99 \AA$ at a depth of 60.0 meters. Chlorite, illite, and kaolinite maintain minor percentages down the section, with chlorite and illite being more abundant than kaolinite.

\section{Sources for Pelagic Clay Minerals at Leg 60 Sites}

The sources for modern and ancient pelagic clays in the South Philippine Sea are discussed in relation to Leg 59 sites by Balshaw (in press). These same general sources also pertain to clay sediments in the Mariana Trough, fore-arc, and the adjacent edge of the western Pacific plate. The detrital clays are mainly derived from hydrothermal alteration of ridge basalts. These include smectites, chlorite, illite, kaolinite, and vermiculite. For a more complete discussion of these clay sources see Balshaw (in press).

\section{Discussion}

\section{Site $\mathbf{4 5 2}$}

This site, drilled on the western edge of the Pacific plate, contains Quaternary pelagic clays deposited under the influence of the deep Western Boundary Current (Moriyasu, 1972) which flows northward to the east of the Mariana Arc. The trace amounts of volcanic glass in sediments from this site document sediment input from the Mariana Arc. There is no apparent change in the

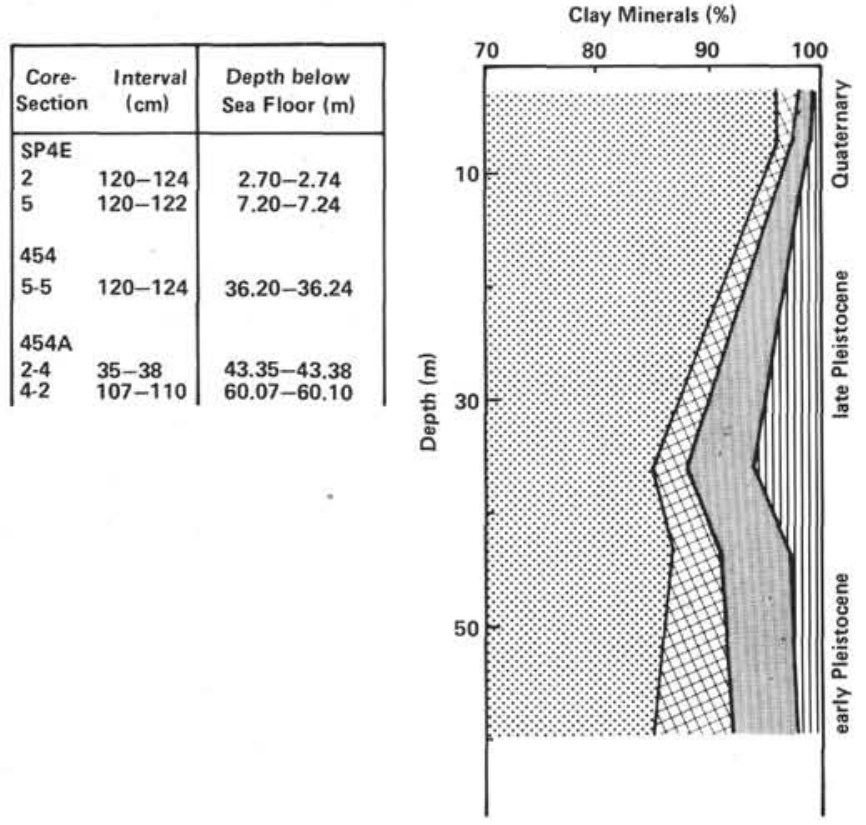

Figure 3. Site 454 , percentages of clay minerals in the $<2-\mu \mathrm{m}$ separates. content of volcanic glass down the section. Therefore, the slight increase in smectite down the section could be a function of increased alteration of volcanic glass with time and depth.

Both random and ordered compositional interstratification in the smectite lattices increases down the section. A shift in the major glycolated smectite peak to values other than $18 \AA$ indicates compositional interstratification within the mineral lattice. Reflections at $d$ spacings smaller than $18 \AA$ result from the presence of randomly distributed layers of chlorite, illite, or possibly vermiculite composition within the smectite lattice. The glycolated smectite peaks showing reflections larger than $18 \AA$ indicate orderly repetition of some of these different compositional layers within the lattice. Random interstratification could signify fairly recent authigenic development of the lattice, perhaps from altering glass in the sediment. Ordered interstratification could result from restructuring of random layers owing to time or elevated temperature or, perhaps, resulting from initial hydrothermal alteration of basalts (Aldrich et al., in press).

\section{Sites 453 and 454 (Hole 454A and Piston Core SP4E)}

These sites in the Mariana Trough contain no pelagic clay units. The general decrease in smectite during the late Pliocene through early Pleistocene corresponds to a decrease of volcanic ash noted in these sediments. Packham et al. (this volume) relate this decrease in ash to increased distance of trough sites from the volcanic arc, rather than to a decrease in volcanism on the Mariana Arc. The smectite decrease is accompanied by an increase in other detrital clay constituents, which is most likely an artifact of calculating the clay percentages. The smectite abundance appears to be strongly connected with the input of glass into these sediments, and the other clay species are probably relatively constant.

At Site 453, the increase in smectite content during the late Pleistocene could be due to a slight increase in volcanic ash content in these upper sediments, an increase in the alteration rate of the ash, or perhaps the transport of more ridge-derived smectite into the trough. Compositional interstratification in the smectites at this site maintains an ordered character down the section. This suggests that the increase in smectite in the late Pleistocene is due to ridge-derived clay.

Site 454 also underwent this increase in smectite during the late Pleistocene, but the increase was more gradual and is associated with decreasing ash content. Because of this decrease in ash content and an increase in ordered compositional smectite interstratification in these sediments, the general smectite increase probably results from ridge-derived clays, as at Site 453 . Ordered compositional smectite interstratification is much more common in Site 453 than Site 454 sediments, however. It is especially apparent from a depth of 35.2 to 125.7 meters at Site 453 and reflects a larger input of ridge-derived smectite to this site due to its proximity to the West Mariana Ridge. 


\section{AUTHIGENIC CLAY STUDY}

\section{ANALYTICAL METHODS}

Eighteen samples, averaging $5 \mathrm{~cm}_{3}$ each, were crushed in a deionized water using a mortar and pestle to dislodge authigenic mineral growths from grain surfaces and fractures. The samples were then chemically treated using the same techniques described in the stratigraphic study section. The magnesium-saturated, glycolated slides were scanned from 4.0 to $40.0^{\circ} 2 \theta$ using a scanning speed of $0.5^{\circ}$ $2 \theta / \mathrm{min}$. and also between 59.0 and $62.5^{\circ} 2 \theta$ at $0.25^{\circ} 2 \theta / \mathrm{min}$. to study the 060 reflections as suggested by Scheidegger and Stakes (1980). The same authors describe techniques for identifying celadonite, "protoceladonite," and saponite that are applied in this study.

\section{Results}

Site 453 is located in the Mariana Trough off the eastern flank of the West Mariana Ridge (latitude $17^{\circ}$ $54.42^{\prime} \mathrm{N}$; longitude $143^{\circ} 40.95^{\prime} \mathrm{E}$ ) in 4693 meters of water. The drill penetrated 446 meters of volcaniclastic sediments before entering igneous breccias. Seven samples were selected from upper Pleistocene through lower Pliocene clay, mud, claystone, and mudstone units ranging from the surface to a depth of 276.1 meters. The major glycolated (dioctahedral) smectite peak $(18 \AA)$ remains fairly constant in height and width from a depth of 4.2 to 105.1 meters, indicating no change in the crystallinity. Below this, to a depth of 276.1 meters, the smectite crystallinity increases with depth; the smectite peak expands in height but not width (Fig. 4). The dominant feldspar in these clay separates is plagioclase with a minor potassium feldspar component which decreases with depth. Celadonite $(1.503 \AA)$ and saponite $(1.535 \AA)$ are found in trace amounts from 4.2 to 103.0 meters depth; below this, celadonite increases slightly and saponite decreases.

The shipboard pore water geochemistry analyses show less calcium than magnesium in near-surface sediment pore waters. Down the section, calcium concentrations increase as magnesium decreases with calcium eventually exceeding $\mathrm{Mg}$ concentrations in the pore water below a depth of approximately 110 meters. These variations in pore water chemistry are linked to the increased production of smectite downhole, from the alteration of ash in these sediments.

Site 456 is located in the Mariana Trough off the western flank of the Mariana Ridge (latitude $17^{\circ} 54.68^{\prime}$ $\mathrm{N}$; longitude $145^{\circ} 10.77^{\prime} \mathrm{E}$ ) in 3586 meters of water. The drill penetrated 114.0 meters of volcaniclastic sediments before entering pillow basalts. Due to poor core recovery, a total of only three samples were analyzed from upper through lower Pleistocene vitric muds, mudstones, and tuff units ranging from 39.7 meters to a depth of 101.2 meters.

The major glycolated smectite (montmorillonite) peak $(17.33 \AA)$ increases in height down the section, as at Site 453. Trace amounts of saponite (1.535 $\AA$ ), and possibly

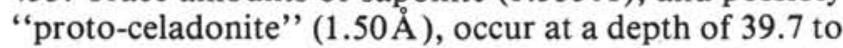
77.7 meters. The "proto-celadonite" is questionable due to low peak amplitude. Below this depth strong wairakite peaks appear (major peak at $3.40 \AA$ ). The $\mathrm{XRD}$ reflections from these samples can correspond to either wairakite or analcite (the sodium analog of the more calcic wairakite). However, wairakite has been

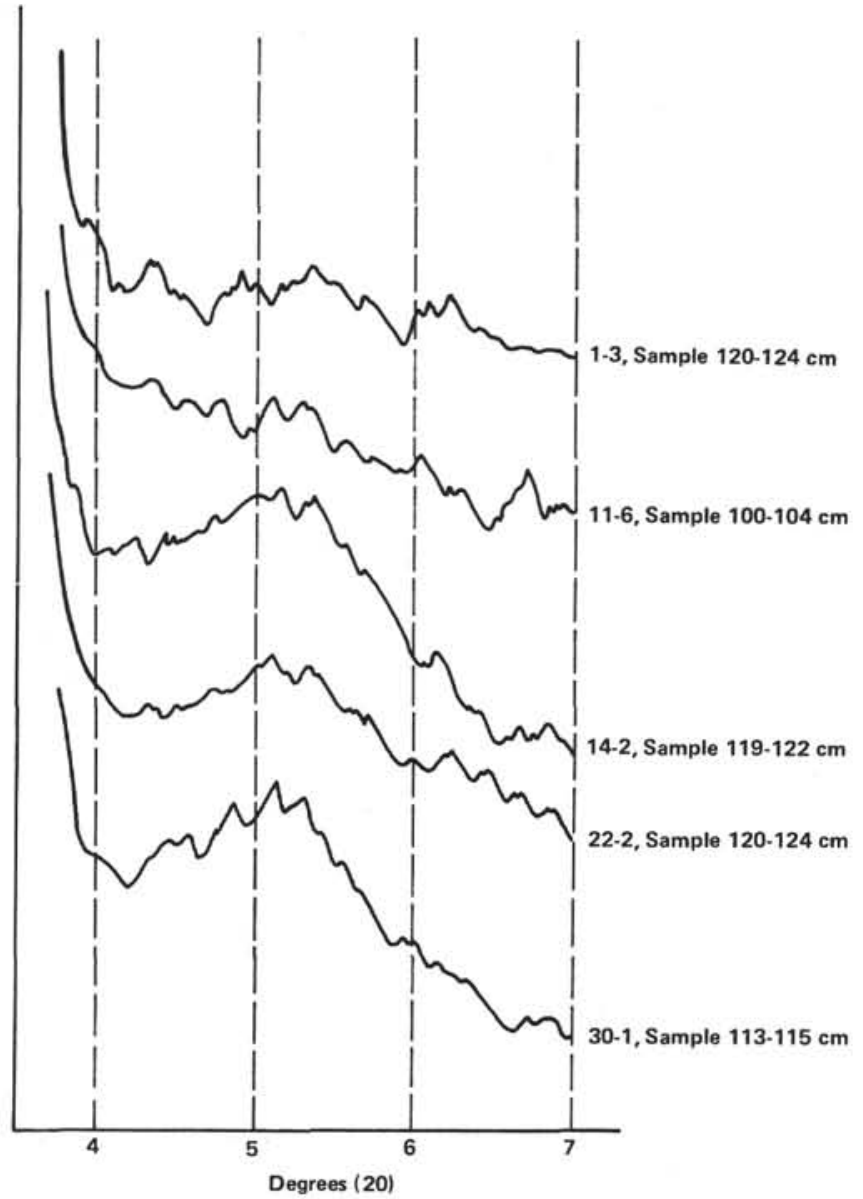

Figure 4. Site 453, glycolated smectite peaks from XRD tracings.

identified at this site in sediments just above basalts using SEM with energy-dispersive X-ray verification (Natland and Hekinian, this volume). This strongly suggests that the zeolite XRD peaks under consideration result from wairakite and not analcite. The dominant feldspars in these clay separates are potassium feldspars.

The shipboard pore water geochemical analyses show that the near-surface sediments contain less calcium than magnesium, with calcium concentrations remaining fairly constant to a depth of 85.0 meters and increasing below this level (Gieskes and Johnson, this volume). Magnesium concentrations are constant to a depth of 40.0 meters, below which they decrease slightly but never equal the same concentration as calcium. It is interesting that Site 456 which mineralogically suggests more oxidizing conditions, also shows more constant $\mathrm{Mg}$ concentrations in the pore waters. Scheidegger and Stakes (1980) explain this condition in other sediments by suggesting that the $\mathrm{Mg}$-rich clays are less stable under oxidizing conditions, so the $\mathrm{Mg}$ in the pore waters is not removed by clay formation. They note that under highly oxidizing conditions, $\mathrm{Mg}$ may even be added back to the pore water by breakdown of the trioctahedral smectite species.

Site 458 is located to the east of the Mariana Ridge in the Mariana fore-arc region (latitude $17^{\circ} 51.85^{\prime} \mathrm{N}$; longitude $146^{\circ} 56.06^{\prime} \mathrm{E}$ ) in 3447 meters of water. The 
drill penetrated approximately 250.0 meters of mixed volcaniclastic and biogenic sediments before entering volcanic basement. Eight samples were selected from middle Miocene vitric ash units ranging from 58.2 meters to a depth of 97.7 meters.

The glycolated smectite (montmorillonite) peaks $(16.99 \AA)$ were low to medium in amplitude and exhibited no general trend down the section. Traces of celadonite $(1.503 \AA$ ) and saponite $1.535 \AA$ ) are found from a depth of 58.2 meters to 77.2 meters. The dominant feldspars in these clay separates are plagioclase.

Shipboard pore water geochemistry studies show trends in calcium and magnesium concentrations similar to those found at Site 453 . The calcium/magnesium concentration cross-over occurs at approximately 130 meters at this site. The sampled interval ends at a depth of 97.7 meters because of poor core recovery. Samples were not selected from depths shallower than 58.2 meters because of the large proportion of biogenic sediment in the upper sediment column.

\section{Conclusions}

\section{Site 453}

Although some of the smectite in the clay separates is detrital, the glycolated smectite peak increases in height down the section, paralleling the increase in calcium and decrease in magnesium concentrations in the pore water analyses. The depth at which the concentrations of these two ions are almost equal is near 110 meters which is in the region where XRD analyses show the smectite component starting to increase. Celadonite also increases slightly at the expense of saponite in this area. This suggests that magnesium is incorporated into the authigenic clay lattices, probably nucleating on the surfaces of altering volcanic glass, whereas calcium is released by the alteration of volcanic ash and deeper basalts. This mechanism is discussed by Lawrence et al. (1975), who find trends similar to those at Leg 60 sites for the behavior of calcium and magnesium in the pore waters at DSDP Sites 70 and 71 . These authors suggest that the mineral changes might be minor enough to go undetected by XRD analysis. This could be the case in the upper sections of Site 453, above 110 meters, where shipboard pore water analyses indicate changes in the calcium and magnesium concentrations that are not reflected by any increase in the authigenic clays. However, Stakes and Scheidegger (in press) find that glass can undergo some chemical modification before it even begins the change to clay. These authors suggest that during hydration to a "palagonitic" type material, a loss of $\mathrm{Ca}$ from the glass and perhaps even a gain of $\mathrm{Mg}$ into a cryptocrystalline smectite could occur before any good smectite peak would be detectable on a diffractogram.

The association of montmorillonite, celadonite, saponite, and primary plagioclase in the clay separates at this site resembles the mineral assemblage found by Scheidegger and Stakes (1980) in fracture fillings and on altered basalt fragments at DSDP Hole 417D. They at- tribute the formation of authigenic montmorillonite, celadonite, $\mathrm{Fe}$-saponite, and the preservation of primary plagioclase to the presence of low-temperature, non-oxidative hydrothermal fluids rich in $\mathrm{Fe}, \mathrm{Mg}$, and $\mathrm{K}$. They contrast this secondary assemblage with that found at DSDP Hole 417A, which contains montmorillonite, "proto-celadonite," lesser saponite, analcite, and secondary potassium feldspar with only minor preservation of primary plagioclase. The pore water conditions for this assemblage are assumed to be low-temperature, $\mathrm{Al}$-rich, and oxidative.

\section{Site 456}

The trends in increased authigenic smectite development down the section at this site are similar to those found at Site 453. However, the calcium and magnesium concentrations in the pore water never develop the strong downhole trends seen at Site 453. The increasing calcium concentration at no point equals or exceeds the decreasing magnesium concentration. Also, the mineral assemblage in the clay separates at Site 456 contains montmorillonite, wairakite, potassium feldspar, minor plagioclase, minor saponite, and possibly "proto-celadonite." This closely resembles the assemblage described by Scheidegger and Stakes (1980) for Hole $417 \mathrm{~A}$. As previously mentioned, the authigenic minerals at Hole 417A resulted from the presence of oxidative, $\mathrm{Al}$-rich, low-temperature pore waters. Under these oxidizing conditions clays will contain less $\mathrm{Al}$. This implies that the pore waters at Site 456 are more oxidizing than those at Site 453.

\section{Site 458}

The consistent low-to-medium amplitude of the glycolated smectite peaks and the lack of sizeable celadonite or saponite peaks suggest there is little authigenic development of these clays at this site. This could be linked to dilution of volcanic glass by nannofossil and foraminiferal oozes which would dilute the concentration of reactive ash surface or perhaps lower the $\mathrm{SiO}_{2}$ concentration in the pore waters below some critical level. The presence of trace amounts of saponite and celadonite plus the dominance of plagioclase in the feldspar regime suggest that the pore water in the 40-meter interval studied is non-oxidative.

\section{ACKNOWLEDGMENTS}

I wish to thank Dr. John Anderson, Dr. Debra Stakes, Dr. John Butler, and Dr. Jim Natland for their helpful comments in reviewing this manuscript.

\section{REFERENCES}

Aldrich, J. B., Tieh, T. T., and Scott, R. B., in press. Alteration of remnant arc debris, Site 448, Leg 59, Palau-Kyushu Ridge, Philippine Sea, DSDP Leg 59. In Kroenke, L., Scott, R. B., et al., Init. Repts. DSDP, 59: Washington (U.S. Govt. Printing Office).

Balshaw, K. M., in press. Cenozoic clay mineral stratigraphy in the South Philippine Sea, DSDP Leg 59. In Kroenke, L., Scott, R. B., et al., Init. Repts. DSDP, 59: Washington (U.S. Govt. Printing Office).

Lawrence, J. R., Gieskes, J. M., and Broecker, W. S., 1975. Oxygen isotope and cation composition of DSDP pore waters and the alteration of Layer II basalts. Earth Planet. Sci. Lett., 27:1-10. 
Moriyasu, S., 1972. Deep waters in the western North Pacific. In Stommel, H., and Yoshida, K. (Eds.), Kuroshio: Physical Aspects of the Japan Current: Seattle (University of Washington Press), pp. 387-408.

Scheidegger, K. F., and Stakes, D. S., 1980. X-ray diffraction and chemical study of secondary minerals from DSDP Leg 51 Holes 417A and 417D. In Donnelly, T., Francheteau, J., Bryan, W.,
Robinson, P., Flower, M., Salisbury, M., et al., Init. Repts. DSDP, 51, 52, 53, Pt. 2: Washington (U.S. Govt. Printing Office), 1253-1263.

Stakes, D. S., and Scheidegger, K. F., in press. Temporary variations in secondary minerals from Nazca Plate basalts. Geol. Soc. Am. Bull., Nazca Plate Monograph. 